\title{
$\nabla$
}

\section{Techniques of digital image analysis for histological quantification of melanin}

\author{
Técnicas de análise de imagem digital para quantificação histológica da
} melanina

\author{
Hélio Amante Miot $^{1}$ \\ Andréia de Almeida Tamega ${ }^{3}$
}

\author{
Gabrielli Brianezi ${ }^{2}$ \\ Luciane Donida Bartoli Miot ${ }^{4}$
}

\begin{abstract}
Morphometric analysis of tissue melanin may quantitatively contribute to research on pigmentation disorders. The authors present three methods for image analysis, which allow for identification of melanin-equivalent pixels in the epidermis using Fontana-Masson stain and, therefore, for the calculation of its percentage in the different epidermal layers. Moreover, they discuss the main elements related to the analysis and the need for rigorous standardization of the process.
\end{abstract}

Keywords: Cluster analysis; Image cytometry; Melanin; Melanosis; Pigmentation disorders

\begin{abstract}
Resumo: A análise morfométrica da melanina tecidual pode subsidiar quantitativamente a pesquisa em discromias. Os autores demonstram três técnicas de análise de imagem digital que permitem a identificação dos pixels equivalentes à melanina na epiderme pela coloração de Fontana-Masson, possibilitando o cálculo da sua porcentagem nas diferentes camadas da epiderme, e discutem os principais elementos relacionados à análise e a necessidade de rigorosa padronização do processo.

Palavras-chave: Análise por conglomerados; Citometria por imagem; Melaninas; Melanose; Transtornos da pigmentação
\end{abstract}

Melanin is the main pigment related to skin color, and its quantification in histological sections can contribute to clinical, pathophysiological and therapeutic research on skin pigmentation disorders. ${ }^{1}$

A histological estimation of melanin is usually made in a qualitative way by an experienced dermatopathologist, based on visual grading of the quartiles $(0$ to $4+$ ) of each of the affected areas evaluated, which are stained with specific stains, such as FontanaMasson. ${ }^{2,3}$ However, morphometric analysis of the pixels that represent the melanin pigment in digital images of histological slides is more sensitive, accura- te, reproducible, and objective than visual grading. It allows for comparison of smaller samples and statistical detection of less prominent differences, favoring blinding of the analysis, reproducibility among laboratories and operationalization the research process. ${ }^{2,4}$ Evaluation of the percentage of pixels equivalent to melanin in samples of the total epidermis, of its layers, or of the dermis seems to be a suitable variable for comparison between groups, since an estimation of the intensity of the individual colors of pixels do not show to be directly useful to research on pigmentation disorders. In addition, its stoichiometric relationship

Received on 06.01.2011.

Approved by the Advisory Board and accepted for publication on 14.02.2011.

* Work conducted at the Department of Dermatology and Radiotherapy, School of Medicine of Botucatu - Universidade Estadual Paulista "Julio de Mesquita Filho" (FMB-UNESP) - Sao Paulo (SP), Brazil.

Conflict of interest: None

Financial funding: None

Dermatologist, PhD - Assistant Professor, Department of Dermatology and Radiotherapy, School of Medicine of Botucatu - Universidade Estadual Paulista "Julio de Mesquita Filho" (FMB-UNESP) - Sao Paulo (SP), Brazil.

Biomedical scientist - MSc student of Pathology, School of Medicine of Botucatu - Universidade Estadual Paulista "Julio de Mesquita Filho" (FMB-UNESP) - Sao Paulo (SP), Brazil.

Dermatologist - MSc student of Pathology, School of Medicine of Botucatu - Universidade Estadual Paulista "Julio de Mesquita Filho" (FMB-UNESP) - Sao Paulo (SP), Brazil.

Dermatologist, PhD - Physician, Department of Dermatology and Radiotherapy, School of Medicine of Botucatu - Universidade Estadual Paulista "Julio de Mesquita Filho" (FMB-UNESP) - Sao Paulo (SP), Brazil. 
with color density has not yet been established. ${ }^{5,6}$

Thus, the use of image processing techniques that allow for segmentation of the pixels equivalent to the melanin of other structures in a selected area may result in an appropriate choice for analysis of pigmentation disorders. ${ }^{3}$ In this study, we discuss three techniques for segmentation of pixels related to epidermal melanin using microscopic digital images of facial skin with melasma and adjacent healthy skin, stained with Fontana-Masson and analyzed by ImageJ v.1.44l software (National Institutes of Health - NIH, Bethesda, Maryland, USA, 2010).

To demonstrate histological quantification of melanin in histological sections (areas of interfollicular epidermis), two slides were photographed with Nikon Coolscope II (Nikon Instruments Inc., Tokyo, Japan, 2009) at 40x magnification, and the 24bit color images, 1280x960 pixels, were stored in .bmp digital files (Figure 1). The amount of epidermal melanin estimated by each method was corrected for the width of each section selected.

After manually determining the area of the epidermis to be evaluated, the first analysis technique to be employed is selection of the Blue component of the RGB (Red-Green-Blue) system, and subsequent automatic segmentation (Otsu method) of pixels (Figures 2 and 3). The ratio of segmented pixels correlates to the presence of melanin pigment in the epidermis.

The blue color channel is the component of the RGB color system that best represents the dark shade of the melanin stained with Fontana-Masson, allowing for proper identification of the pigment. ${ }^{3}$

A second form of melanin identification occurs, based on the epidermal area selected, by segmentation


FIGURE 1: Photomicrographs of the epidermis of patients with facial melasma: normal skin (A) and damaged skin (B) stained with Fontana-Masson (40x)
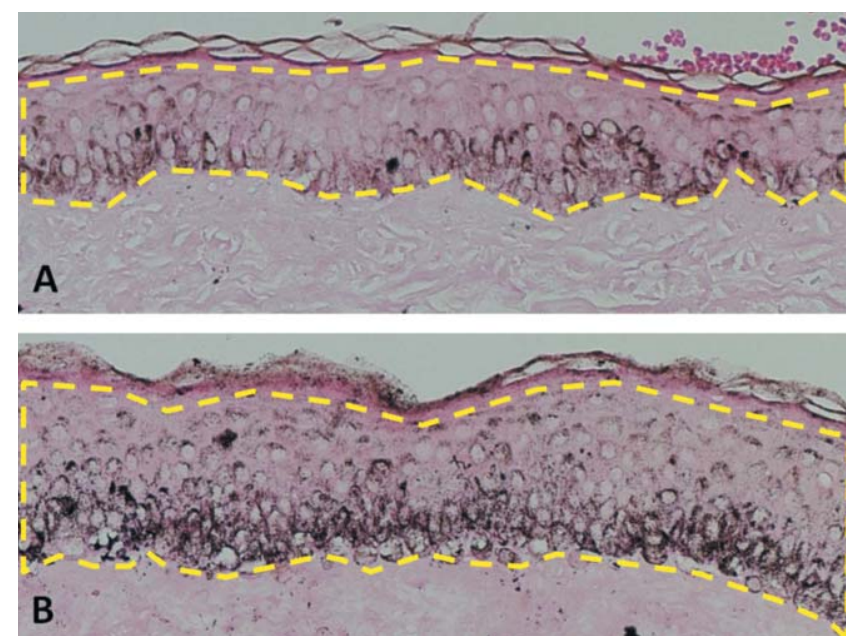

FiguRE 2: Manual selection of the epidermal region (interfollicular) to be analyzed: normal skin (A) and damaged skin (B) stained with Fontana-Masson (40x)

of two color clusters and calculation of the pixels composing the clusters that represent melanin (Figure 4).

The k-means clustering algorithm considers the Euclidean distance of all pixels in the region of interest projected in an orthogonal space of its $\mathrm{RxGxB}$ components. That is, if each pixel is represented by a coordinate point $(R, G, B)$, the virtual linear distance between them can be estimated and groups of pixels of similar color can be formed. The algorithm replaces their original values with their $k$ centroids and forms an image with $k$ colors. This is a quick and efficient method for separating histochemical stains such as Masson's trichrome and Hematoxylin-Eosin, in addition to being little sensitive to variations in color saturation and image brightness. ${ }^{8,9}$

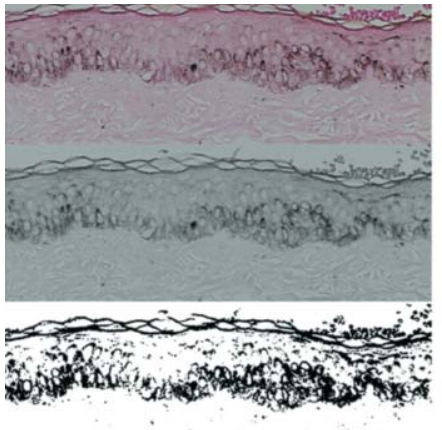

A



B
Figure 3: Original image, selection of the blue color channel and automatic segmentation using Otsu's algorithm. Healthy skin (A) resulted in 66785 pixels equivalent to the melanin present from the basal to the granular layer; skin with melasma (B) resulted in 76800 pixels. Values corrected for the width of each section selected 


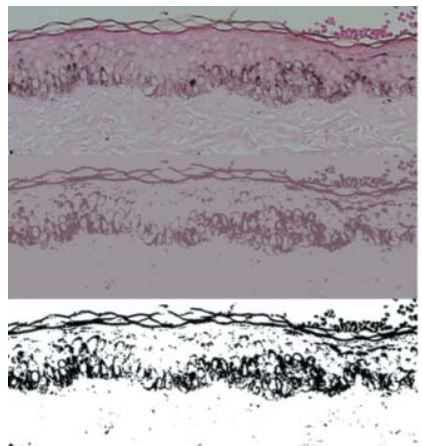

A



B

FiguRE 4: Original image, segmentation of the area selected using the $k$-means clustering technique in two color clusters. Healthy skin (A) resulted in 4793 pixels equivalent to the melanin present from the basal to the granular layer; skin with melasma (B) resulted in 76803 pixels. Values corrected for the width of each section selected

Another way of identifying the pixels corresponding to melanin in a histological section results from representation of the flow of similar and adjacent pixels by coherence-enhancing anisotropic diffusion filtering, allowing for estimation of the pixels corresponding to melanin after automatic segmentation (Otsu method) of the histogram (Figure 5).

Anisotropy of the image refers to the direction of the structures or sequences of pixels, whose coherence can be measured. The coherence-enhancing diffusion filter builds a connection between the flow of pixels with similar intensity, which, in the epidermis, may represent melanin production and distribution in the basal layers, allowing for inferences concerning differences in the activity of the epidermal-melanin unit of the samples. ${ }^{10}$

Methods of computational morphometric evaluation of melanin must be considered for quantitative analysis in research on pigmentation disorders. However, none of the techniques discussed above is absolute, infallible or completely related to each other, since different processing algorithms are used. All of them suffer strong interference of rigorous standardization of the process of collecting and preparing specimens, in addition to the need for sufficient samples for evidence-based conclusions.

It is observed that the stratum corneum, since it absorbs the histochemical stain, is selected when automatic segmentation algorithms are used and must be manually excluded from the analysis.

Comparison of epithelia of different thickness is not recommended for calculating the proportion or


B

FIGURE 5: Original image, coherence-enhancing anisotropic diffusion filtering (two interactions), manual selection of epidermal layers. Healthy skin (A) resulted in 63921 pixels equivalent to the melanin present from the basal to the granular layer; skin with melasma (B) resulted in 71851 pixels. Values corrected for the width of each section selected

percentage of epidermal melanin as quantitative indices, since distribution of the pigment is irregular and its concentration is higher in the deeper layers of the epidermis. Estimation of the total number of pixels corresponding to melanin in the selected area of the tissue proves to be a more reliable index; however, it requires correction in terms of width of the selected epidermal area, as we did in these cases. ${ }^{5,11}$

Blinding of the analysis and use of various skin sections and images for each case reduce the chances of selection bias and increase the internal validity of the experiment. Furthermore, validation of the results of automated algorithms via visual qualitative analysis by an experienced dermatopathologist is highly recommended, even if it includes only subsets of the sample, in order to control the quality of the results of the experiments.

Measures of the algorithms can be controlled based on linear correlation between automated indices and qualitative visual estimation. Correlation coefficients below 0.7 should indicate reassessment of the methodology and risk of compromising the validity of the results.

The study of skin melanin in pigmentation disorders can also be supplemented by clinical, colorimetric, and chromatographic analysis; confocal microscopy; Raman spectroscopy; electron microscopy; and indicators of melanocytic activity, such as the presence, activity, and gene expression of tyrosinase, estimated by immunohistochemistry, zymography, or RT-PCR. ${ }^{12-20} \square$ 


\section{REFERENCES}

1. Miot LD, Miot HA, Silva MG, Marques ME. Fisiopatologia do melasma. An Bras Dermatol. 2009;84:623-35

2. Oberholzer M, Ostreicher M, Christen H, Bruhlmann M. Methods in quantitative image analysis. Histochem Cell Biol. 1996;105:333-55.

3. Brianezi G, Miot HA. Desenvolvimento e validação de técnica quantitativa de análise de imagem para avaliação do teste do cometa corado pela prata. J Bras Patol Med Lab. 2009;45:325-34.

4. Lee ES, Kim JH, Im S, Lee KB, Sohn S, Kang WH. Application of computerized image analysis in pigmentary skin diseases. Int J Dermatol. 2001;40:45-9.

5. Meijer GA, Belien JA, van Diest PJ, Baak JP. Origins of ... image analysis in clinical pathology. J Clin Pathol. 1997;50:365-70.

6. Miot LDB, Miot HA, Silva MG, Marques MEA. Estudo comparativo morfofuncional de melanócitos em lesões de melasma. An Bras Dermatol. 2007;82:529-34.

7. Papadopulos F, Spinelli M, Valente S, Foroni L, Orrico C, Alviano F, et al. Common tasks in microscopic and ultrastructural image analysis using ImageJ. Ultrastruct Pathol. 2007;31:401-7.

8. Miot HA, Brianezi G. Morphometric analysis of dermal collagen by color clusters segmentation. An Bras Dermatol 2010;85:361-4.

9. Smolle J. Computer recognition of skin structures using discriminant and cluster analysis. Skin Res Technol. 2000;6:58-63.

10. Weickert J. Coherence-Enhancing Diffusion Filtering. Int $\mathrm{J}$ Comp Vis. 1999;31:111-27.

11. Miot LD, Miot HA, Polettini J, Silva MG, Marques ME. Morphologic changes and the expression of alpha-melanocyte stimulating hormone and melanocortin-1 receptor in melasma lesions: a comparative study. Am J Dermatopathol. 2010;32:676-82.

12. Donois E, del Marmol V, Taïeb A, Ghanem G, Surlève-Bazeille JE. Quantification of eumelanin and pheomelanin: stereologic image analysis method. Anal Quant Cytol Histol. 1998;20:275-87.

13. Kainerstorfer JM, Ehler M, Amyot F, Hassan M, Demos SG, Chernomordik V, et al. Principal component model of multispectral data for near real-time skin chromophore mapping. J Biomed Opt. 2010;15:046007.
14. Yamamoto T, Takiwaki H, Arase S, Ohshima H. Derivation and clinical application of special imaging by means of digital cameras and Image $\mathrm{J}$ freeware for quantification of erythema and pigmentation. Skin Res Technol. 2008;14:26-34.

15. Kang HY, Bahadoran P, Ortonne JP. Reflectance confocal microscopy for pigmentary disorders. Exp Dermatol. 2010;19:233-9.

16. Ardigo M, Cameli N, Berardesca E, Gonzalez S. Characterization and evaluation of pigment distribution and response to therapy in melasma using in vivo reflectance confocal microscopy: a preliminary study. J Eur Acad Dermatol Venereol. 2010;24:1296-303.

17. Huang Z, Lui H, Chen XK, Alajlan A, McLean DI, Zeng H. Raman spectroscopy of in vivo cutaneous melanin. J Biomed Opt. 2004;9:1198-205.

18. Oh MJ, Abdul Hamid M, Ngadiran S, Seo YK, Sarmidi MR, Park CS. Ficus deltoidea (Mas cotek) extract exerted anti-melanogenic activity by preventing tyrosinase activity in vitro and by suppressing tyrosinase gene expression in B16F1 melanoma cells. Arch Dermatol Res. 2011;303:161-70.

19. Xu AE, Huang B, Li YW, Wang P, Shen H. Clinical, histopathological and ultrastructural characteristics of naevus depigmentosus. Clin Exp Dermatol. 2008;33:400-5.

20. Kingo K, Aunin E, Karelson M, Philips MA, Rätsep R, Silm H, et al. Gene expression analysis of melanocortin system in vitiligo. J Dermatol Sci 2007;48:113-22.

\author{
MAILING ADDRESS: \\ Hélio Amante Miot \\ Departamento de Dermatologia da Faculdade de \\ Medicina da Unesp, $S / N$. \\ Campus Universitário de Rubião Jr. \\ 18618-000 - Botucatu, SP \\ E-mail address: heliomiot@fmb.unesp.br
}

How to cite this article: Miot HA, Brianezi G, Tamega AA, Miot LDB. Techniques of digital image analysis for histological quantification of melanin. An Bras Dermatol. 2012;87(4):608-11. 